\title{
PENGARUH VARIASI JARAK PADA BESI BETON YANG BERFUNGSI SEBAGAI ANGKUR PENGHUBUNG GESER
}

\author{
Rhini Wulan Dary \\ Dosen Pengajar Program Studi Teknik Sipil, Fakultas Teknik, UMSU, Medan \\ Surel : rhini_wede@yahoo.com \\ Diterima : 13 Oktober 2017; Disetujui : 20 Oktober 2017
}

\begin{abstract}
ABSTRAK
Besi beton biasanya digunakan sebagai tulangan pada struktur beton. Namun kali ini, besi beton digunakan sebagai penghubung geser antara struktur beton dan baja. Pada penelitian laboratorium ini digunakan besi beton dengan pemasangan tipe post installed yakni bonded anchor dengan mutu beton $\mathrm{f}^{\prime} \mathrm{c} 25 \mathrm{Mpa}$. Metode pengetesan dengan cara push-out-test. Benda uji yang dibuat terdiri dari 3 buah benda uji dengan variasi jarak antara besi beton sebesar $40 \mathrm{~mm}, 64 \mathrm{~mm}$ dan $90 \mathrm{~mm}$. Pengamatan perilaku besi beton menggunakan dial gauge per titiknya. Besi beton yang dipasang pada sebuah benda uji terdiri dari 12 buah besi beton. Percobaan laboratorium ini dibuat guna mengetahui perilaku besi beton terhadap variasi jarak sebagai angkur penghubung geser.
\end{abstract}

Kata Kunci : besi beton, penghubung geser, push-out-test, variasi jarak

\begin{abstract}
Rebar is usually used as a reinforcement on a concrete structure. However this time, rebar is used as a shear connector between concrete and steel structures. In this laboratory research is used rebar with installation of post installed type that is bonded anchor with quality of concrete $f^{\prime} c 25 \mathrm{Mpa}$. Test method by push-out-test. The test specimen made consisted of 3 pieces of specimen with variation of distance between rebar by $40 \mathrm{~mm}, 64 \mathrm{~mm}$ and $90 \mathrm{~mm}$. Observation of rebar behavior using dial gauge per point. The rebar mounted on a specimen consists of 12 concrete pieces of rebar. This laboratory experiment was made to determine the behavior of rebar against the distance variation as a shear connector.
\end{abstract}

Keywords: distance variation, rebar, shear connector, push-out-test

\section{Pendahuluan}

Semakin menjamurnya pembangunan, lahan yang digunakan untuk pembangunan pun semakin sedikit sehingga tidak jarang para pemilik gedung yang berkeinginan merubah fungsi bangunannya lebih memilih memperkuat bangunannya dengan merenovasi daripada membangun kembali bangunannya. Salah satu cara memperkuat bangunan struktur beton adalah dengan menggunakan baja sebagai tambahan. Adapun penghubung yang digunakan antara struktur beton dengan baja tersebut yakni angkur. Angkur yang umum digunakan pada pelaksanaan lapangan adalah baut angkur. Akan tetapi pada penelitian ini penghubung geser yang digunakan berupa besi beton. Dengan menimbang bahwa harga besi beton lebih murah dan mudah diperoleh daripada baut angkur.

\section{Kajian Pustaka}

\subsection{Klasifikasi Angkur}

Mekanisme beban transfer angkur menentukan karakteristik kinerja angkur. Angkur dapat diklasifikasikan ke dalam dua kategori utama yaitu cast in place dan post installed.

Dalam penelitian ini, digunakan angkur post installed dengan tipe bonded anchor dimana beton yang sudah mengeras terlebih dahulu dilubangi dengan ukuran diameter lubang 
angkur dimasukkan ke dalam lubang, diberikan cairan perekat chemical anchor guna memberi perekat antara angkur dengan betonnya.

\subsection{Ketentuan Spasi Angkur}

Dalam merencanakan sambungan, ada persyaratan jarak antara angkur yang harus dipenuhi. Peraturan yang digunakan dalam hal ini menggunakan Peraturan ETAG 001 Edition 1997; Guideline for European Techinal Approval of Metal Anchors for Use in Concrete; Annex C : Design Methods for Anchorages, 2010.

Kelompok angkur dengan rangkaian angkur tunggal dengan posisi pada ujung beton maka ketentuan spasi angkur dengan pinggir beton. Di dalam penggunaannya, angkur dapat dipasang secara seri dan paralel. Di dalam peraturan ETAG juga disebutkan ketentuan spasi antara pinggir beton dengan angkur, spasi antara angkur ke angkur dan tebalnya beton yang direncanakan. Hal ini dapat kita lihat pada Gambar 1.

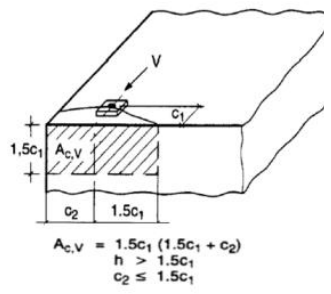

(a)

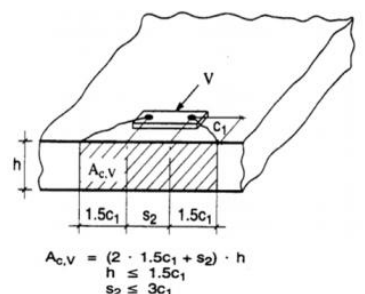

(b)

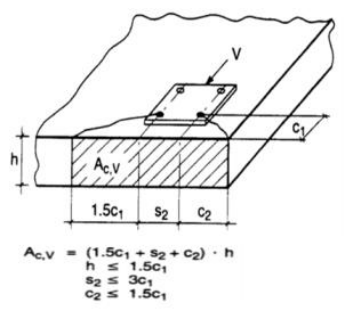

(c)

Gambar 1. (a) Kelompok angkur tunggal; (b) Kelompok angkur pada rangkaian seri; (c) Kelompok angkur pada rangkaian paralel (ETAG 001 Edition, 1997)

\section{Metodologi}

Benda uji kubus beton yang digunakan mempunyai ukuran panjang $200 \mathrm{~mm}$, lebar 300 $\mathrm{mm}$ dan tinggi $400 \mathrm{~mm}$ tanpa menggunakan tulangan sebanyak enam buah. Dimensi profil baja yang digunakan H-Beam (200x200x8x12) mm sebanyak tiga buah dengan tinggi masingmasing $280 \mathrm{~mm}, 328 \mathrm{~mm}$ dan $389 \mathrm{~mm}$. Besi beton yang digunakan sebagai penghubung geser tipe BjTS (Baja Tulangan beton Sirip) diameter $8 \mathrm{~mm}$ yang sudah diulir pada bagian ujungnya sebagai tempat penempatan ring dan mur nya sebanyak 36 buah. Epoxy type MF-EX2 $360 \mathrm{ml}$ high strength epoxy digunakan sebagai perekat antara besi beton dengan betonnya.

Beton yang sudah mencapai umur 28 hari, dilubangi sebagai tempat perletakan besi beton yang akan diepoxy dengan variasi jarak antar angkurnya $40 \mathrm{~mm}, 64 \mathrm{~mm}$ dan $90 \mathrm{~mm}$. Desain benda uji dapat dilihat pada Gambar 2.

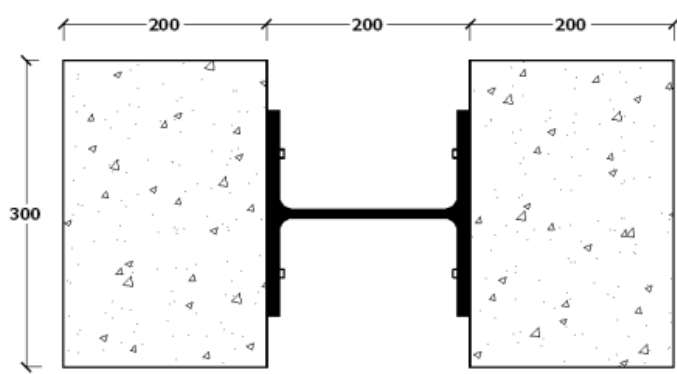

(a)

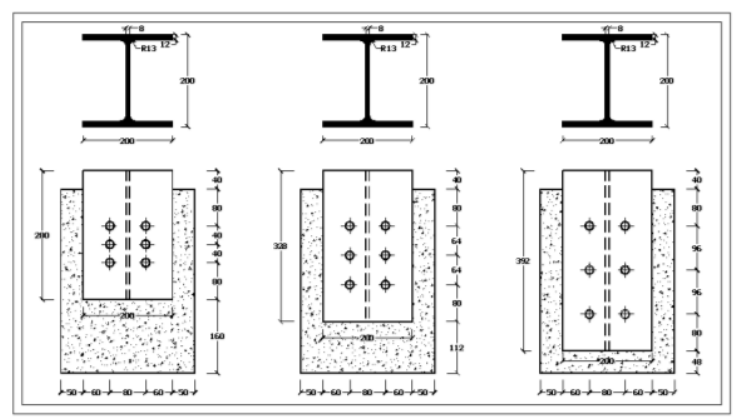

(b)

Gambar 2. Pemodelan benda uji; (a) benda uji tampak atas ; (b) benda uji tampak samping dengan jarak antar angkur 40 $\mathrm{mm}, 64 \mathrm{~mm}$, dan $96 \mathrm{~mm}$

Pembersihan lubang pada beton tersebut dengan menggunakan blower dengan tujuan agar sisa debu yang menempel pada kubus beton dapat diminimalisir sehingga diharapkan epoxy yang akan diinjeksi akan mempunyai daya rekat yang tinggi antara besi beton dengan kubus betonnya. Setelah epoxy mongering lakukan penyatuan benda uji kubus beton yang sudah dipasang besi beton sebagai angkur dengan profil baja H-Beam, sehingga benda uji terlihat pada Gambar 3. 


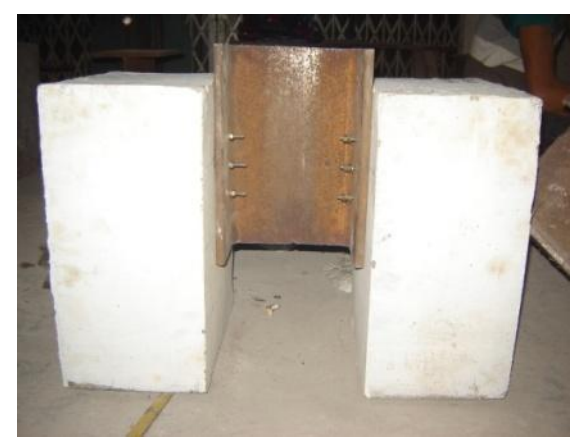

Gambar 3. Benda uji

Benda uji yang siap dirangkai, diletakkan pada frame baja untuk dilakukan push-out-test. Di dalam pengujian benda uji dipasang track stang guna menghindari momen dan puntir. Beban yang diberikan merupakan beban geser murni. Pembebanan diberikan secara bertahap sebesar $500 \mathrm{~kg}$ hingga mencapai keruntuhan pada besi betonnya. Pada masing-masing titik besi beton dipasang alat dial gauge guna mengetahui deformasi dan perilaku besi beton. Pembebanan diberikan dengan menggunakan alat jack hydraulic. Kemudian catat dan amati perilaku besi beton yang terjadi. Perletakan benda uji dapat dilihat pada Gambar 4 .

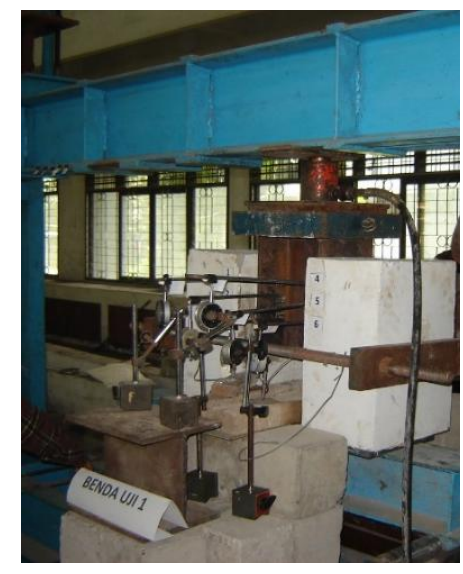

Gambar 4. Percobaan dengan push-out-test

\section{Hasil dan Pembahasan}

Setelah melakukan pengujian laboratorium, dapat diperoleh hasil pengujian hingga besi beton mengalami keruntuhan. Masing-masing perilaku keruntuhan besi beton berbeda-beda sesuai dengan variasi jarak yang telah direncanakan. Pembacaan deformasi yang terjadi pada besi beton dilakukan dengan alat dial gauge. Deformasi yang dihasilkan dapat dilihat pada Gambar 5 .

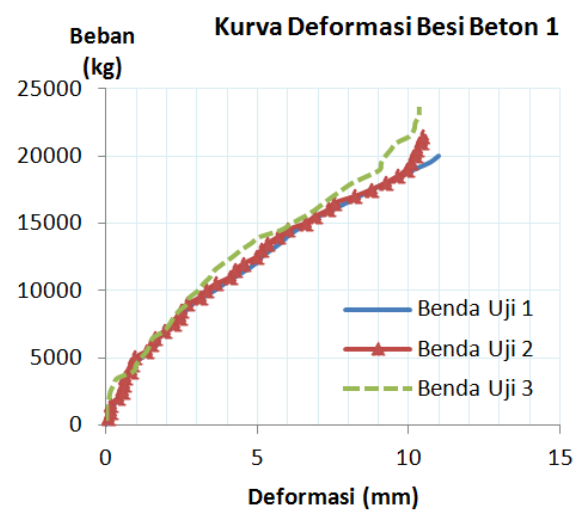

(a)

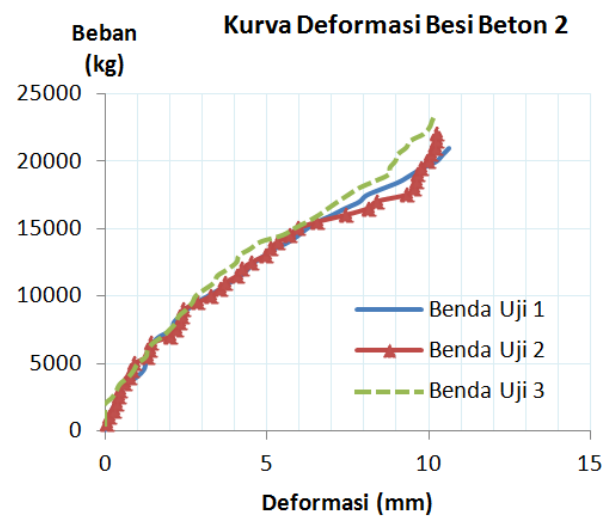

(b)

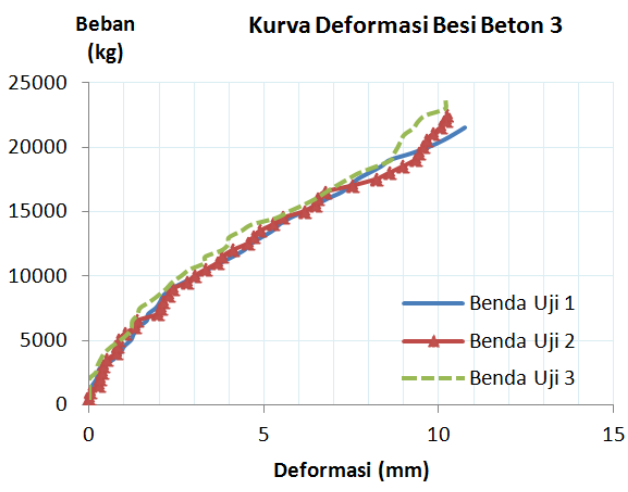

(c)

Gambar 5: Kurva deformasi (a) pada besi beton 1; (b) pada besi beton 2; (c) pada besi beton 3

Dari hasil grafik yang telah disajikan di atas dapat kita lihat bahwa pada benda uji 1 pembebanan bertahap per $500 \mathrm{~kg}$ terus dilakukan, sehingga pada saat beban yang diberikan sebesar 20 ton besi beton nomor 1 mengalami kegagalan, kemudian beban terus diberikan hingga 21.5 ton, besi beton nomor 2 mengalami kegagalan. Dan pada saat beban mencapai 22 ton, besi beton nomor 3 menyusul putus. Besi beton yang paling atas yang mengalami keruntuhan terlebih dahulu 


\section{Rhini Wulan Dary}

daripada besi beton yang berada di bawahnya disebabkan besi beton teratas yang menerima beban pertama sekali. Hasil percobaan laboratorium dapat dililhat pada Gambar 6.
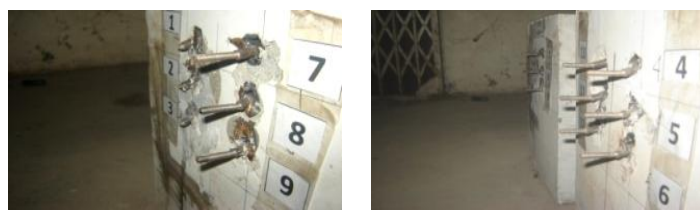

Gambar 6: Besi beton pada benda uji 1 yang sudah mencapai kondisi ultimate

Untuk benda uji 2, pada saat beban yang diberikan sebesar 22.0 ton, besi beton nomor 1 mengalami kegagalan. Pembebanan bertahap dilanjutkan, sehingga pada saat beban yang diberikan sebesar 22.5 ton, besi beton nomor 2 mengalami kegagalan. Dan pada saat beban mencapai 23.0 ton, besi beton nomor 3 menyusul putus. Hal ini terjadi disebabkan beban tidak sentris, sehingga besi beton dengan nomor 1,2 dan 3 yang mengalami putus.

Keretakan yang terjadi lebih sedikit jika dibandingkan dengan benda uji 1, faktor mutu beton yang tinggi dan semakin jarangnya jarak antar besi beton mempengaruhi keretakan yang terjadi pada permukaan beton. Hasil pengujiannya dapat dilihat pada Gambar 7.
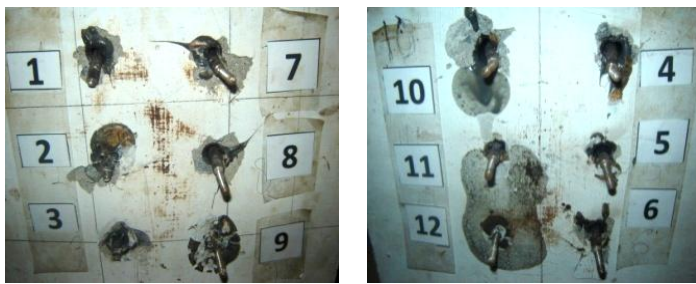

Gambar 7: Besi beton pada benda uji 2 yang sudah mencapai kondisi ultimate

Untuk benda uji 3 pembebanan dilakukan hingga besi beton mencapai kondisi ultimate namun karena kapasitas alat jack hydraulic hanya mampu memberikan beban maksimum sebesar 23 ton, maka pembebanan dihentikan. Untuk benda uji 3 ini, pembebanan maksimum sudah dilakukan tetapi besi beton belum juga putus.

Keretakan yang terjadi hampir tidak kelihatan, yang disebabkan karena semakin jarangnya jarak antara besi beton. Hal ini juga yang menyebabkan besi beton tidak mengalami putus, karena distribusi beban dan faktor jarak yang mempengaruhinya. Hasil pengujiannya dapat dilihat pada Gambar 8
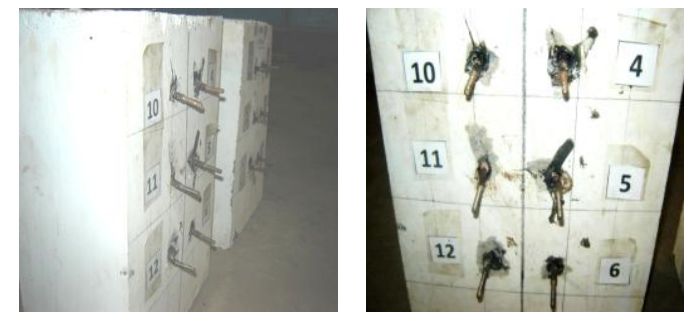

Gambar 8: Besi beton benda uji 3 tidak mengalami kondisi ultimate

Dari grafik terlihat bahwa jarak antar besi beton sangat berpengaruh pada kekuatan struktur. Jarak minimum antar besi beton harus diperhatikan, semakin besar jarak besi beton yang direncanakan maka kegagalan dapat diminimalisir. Dalam penelitian ini dengan mutu beton $\mathrm{f}^{\prime} \mathrm{c} 25 \mathrm{Mpa}$, beton mempunyai kekuatan yang tinggi sehingga karena besi beton bersifat daktail, besi beton akan terus berdeformasi hingga apabila beban geser diberikan terus menerus maka lama kelamaan besi beton akan mengalami kegagalan.

\section{Simpulan}

Setelah dilakukannya penelitian, maka diperoleh beberapa simpulan sebagai berikut:

1) Pada pengujian eksperimental, keruntuhan yang pertama sekali terjadi pada besi beton dengan beban tertentu dan hanya sedikit keretakan beton yang terjadi disebabkan faktor mutu beton yang tinggi.

2) Semakin besar jarak antara besi beton maka deformasinya juga makin kecil, dan makin meningkatnya beban yang dapat dipikul oleh konstruksi tersebut.

3) Dalam rangkaian penelitian ini, besi beton yang pertama sekali putus adalah besi beton yang paling atas, kemudian menyusul besi beton yang di tengah dan kemudian besi beton paling bawah.

4) Perbedaan persentase uji laboratorium, dari besi beton paling atas ke besi beton di bawahnya, pada benda uji 1 besi beton paling atas putus pada saat beban yang diberikan 20 ton kemudian persentase perbedaan dengan besi beton di bawahnya sebesar $6.47 \%$, pada benda uji 2 sebesar $7.62 \%$ dan $16.03 \%$, pada benda uji 3 sebesar $2.22 \%$ dan $13.67 \%$. 


\section{Daftar Pustaka}

Anderson, Neal S, P.E., S.E., dan Meinheit, Donald.F, Ph.D.,P.E.,S.E., Pryout Capacity of Cast in Headed Stud Anchors. PCI-Journal.

Anonim, 1997, Guideline for European Technical Appropal of Metal Anchors for Use in Concrete (ETAG-001), European Organisation for Technical Approvals (EOTA).

Anonim, 2004, Eurocode 4, EN 1994-1-1: Design of Composite Steel and Concrete Structures - Part 1-1: General Rules and Rules for Buildings, European Committee for Standardization.

Evency, Andriana AR, Dharma. Giri I.B, dkk. 2013. Pengujian Kekuatan Penghubung Geser yang Terbuat dari Baja Tulangna Berbetnuk L yang Dibengkokkan dengan Sudut 45 Derajat. Jurnal Ilmiah Elektronik Infrastruktur Teknik Sipil, Volume 1, No.1, Februari 2013. Denpasar. Iswandi, 2013, Studi Eksperimental Perilaku Baut Angkur Pada Kolom Beton Akibat Geser Murni, Tesis Program Studi Magister Teknik Sipil Universitas Sumatera Utara, Medan.

Muratli, Hakki. B.S. 1998. Behavior of Shear Anchors in Concrete : Statistical Analysis and Design Recommendations. Thesis Master of Science in Engineering University of Texas at Austin. Texas.

Rao,G.Appa, Strength of Bonded Anchors in Concrete in Direct Tension, Research student, Departemen of Civil Engineering Indian Institute of Technology Madras, Chennai-600 036, India.

Widiarsa, I.B.R., dan Deskarta, Putu., 2007, "Kuat Geser Baja Komposit dengan Variasi Tinggi Penghubung Geser Tipe-T Ditinjau dari Uji Geser Murni", Jurnal Ilmiah Teknik Sipil, Volume 11, No. 1, Program Studi Teknik Sipil, Universitas Udayana.

Wiston Wayne Clendennen, 1994, Performance of Post-Installed Anchors Under Oblique And Group Loading Conditions in Uncracked Concrete, Thesis, The Graduate School, University of Texas at Austin, USA. 